\title{
PERANCANGAN SISTEM MONITORING PENGGANTIAN OLI PADA SEPEDA MOTOR BERDASARKAN JARAK TEMPUH
}

\author{
Ketut Abimanyu' ${ }^{1}$, Nina Lestari ${ }^{2}$, Muhamad Anton Fauzi ${ }^{3}$, Aji Nurcahya ${ }^{4}$ \\ 1,2,3,4 Program Studi Teknik Elektro, Universitas Sangga Buana \\ ${ }^{1}$ korespondensi : ketut.abimanyu@gmail.com
}

\begin{abstract}
ABSTRAK
Perawatan mesin pada sepeda motor sangat penting diperhatikan untuk mengurangi terjadinya kerusakan mesin pada kendaraan tersebut. Salah satu perawatan utamanya adalah penggantian oli mesin secara teratur. Penggantian oli mesin harus memperhatikan jarak tempuh kendaraan antara 1500-4000 km. Umumnya, sepeda motor belum dilengkapi dengan sistem peringatan untuk melakukan penggantian oli. Oleh karena, itu sistem peringatan pengganti oli dengan berpatokan pada jarak tempuh sangat diperlukan. Permasalahan yang muncul adalah bagaimana cara membandingkan jarak tempuh yang dihitung oleh sistem dengan speedometer digital pada kendaraan. Selain itu sistem harus bisa mendeteksi kapan kendaraan harus melakukan penggantian oli setelah mencapai jarak tempuh tertentu. Pada penelitian ini, sensor yang digunakan adalah sensor proximity yang bekerja secara induktif. Digunakan pula arduino uno sebagai sistem pengolah data, dimana hasil pengolahan data akan ditampilkan dalam bentuk pesan peringatan ganti oli yang akan menyalakan LED indikator dan ditampilkan di LCD. Sistem yang telah direalisasikan, diuji dengan cara membandingkannya dengan jarak tempuh speedometer asli kendaraan. Berdasarkan tes uji, sistem dapat menampilkan peringatan pergantian oli pada jarak tertentu dengan hasil akurasi sistem sebesar $\pm 10 \%$ jarak pada tempuh $10 \mathrm{~km}$.
\end{abstract}

keywords : sepeda motor, oli, jarak, speedometer, proximity

\section{PENDAHULUAN}

Salah satu alat transportasi yang paling diminati oleh masyarakat Indonesia adalah sepeda motor, karena lebih praktis dan ekonomis dalam penggunaannya jika dibandingkan dengan alat transportasi lainnya. Seiring dengan berjalannya waktu, kendaraan membutukan perawatan untuk mengurangi terjadinya kerusakan mesin, Salah satunya adalah penggantian oli secara rutin[1].

Oli berfungsi melumasi komponen logam atau metal yang bergesekan dalam mesin untuk menjaga performa mesin kendaraan tetap prima[2]. Jika terlambat, akan timbul gejalagejala yang dapat merusak mesin, seperti tenaga mesin yang semakin melemah, suhu pada mesin yang meningkat secara cepat, dan asap knalpot yang keluar berlebihan.

Pergantian oli secara rutin atau biasa digabungkan pada istilah service kendaraan dapat dilakukan oleh pengguna kendaraan sendiri atau melalui bengkel dengan memperhatikan waktu service[3]. Waktu service dapat diketahui melalui mengkonversi putaran roda kendaraan menjadi jarak tempuh[4].

Pada Sepeda motor Pergantian oli dilakukan jika Jarak tempuh yang tercapai lebih dari 2000 $\mathrm{Km}$, terkecuali pada servis pertama dikarenakan mesin masih dalam keadaan masih baru jadi diharuskan pergantian di Km 1000[4]. 
Secara umum, sepeda motor pabrikan belum dilengkapi dengan sistem peringatan untuk penggantian oli. Oleh karena, itu sistem peringatan pengganti oli berdasarkan jarak tempuh dapat menjadi sebuah pilihan utama pengembangan.

\section{PERANCANGAN SISTEM}

Komponen-komponen yang digunakan pada penelitian ini antara lain:

1. Sensor proximity bekerja berdasarkan jarak objek terhadap sensor, ketika ada objek logam yang mendekat kepadanya dengan jarak yang sangat dekat, sensor akan bekerja dan menghubungkan kontaknya. Kemudian melalui kabel yang tersedia bisa dihubungkan ke perangkat lainnya seperti lampu indikator, relay, dan lain-lain. Pada saat sensor ini sedang bekerja atau mendeteksi adanya logam (besi) maka akan ditandai dengan lampu kecil berwarna merah atau hijau yang ada dibagian atas sensor, sehingga memudahkan kita dalam memonitor kerja sensor atau ketika melakukan preventive maintenance[5].

\section{Gambar 1 : Sensor Inductive Proximity}

2. Arduino Uno adalah board mikrokontroler berbasis ATMega328. Memiliki 14 pin Input/Output Digital. Untuk mendukung mikrokontroler agar dapat digunakan, cukup dengan menghubungkan board Arduino Uno ke komputer dengan menggunakan kabel USB, power supply atau baterai untuk menjalankannya[6]. Arduino digunakan sebagai pengolah data hasil pembacaan sensor agar dapat ditampilkan menjadi jarak tempuh secara digital

\section{Tabel 1 Spesifikasi Arduino Uno}

\begin{tabular}{|c|c|c|}
\hline No & Spesifikasi & Deskripsi \\
\hline 1 & Mikrokontroler & ATmega 328 \\
\hline 2 & Operasi tegangan & 5 Volt \\
\hline 3 & Input tegangan disarankan & $7-11$ Volt \\
\hline 4 & Input tegangan batas & $6-20$ Volt \\
\hline 5 & Pin I/O digital & 6 \\
\hline 6 & Pin Analog & $520 \mathrm{~mA}$ \\
\hline 7 & Arus DC tiap pin I/O & $50 \mathrm{Ma}$ \\
\hline 8 & Arus DC ketika 3.3V & $2 \mathrm{~KB}($ ATmega328) \\
\hline 9 & Memori flash & 32 KB (ATmega328) \\
\hline 10 & SRAM & $16 \mathrm{MHz}$ \\
\hline 11 & EEPROM & $68.6 \mathrm{~mm} \times 53.4 \mathrm{~mm}$ \\
\hline 12 & Kecepatan clock & $25 \mathrm{~g}$ \\
\hline 13 & Dimensi & \\
\hline 14 & Berat & . \\
\hline
\end{tabular}




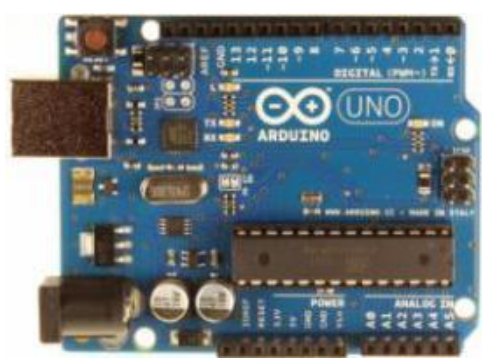

Gambar 2 : Arduino Uno

3. IC Regulator yang digunakan adalah menjadi 5 volt untuk memberikan supply LM7805. IC Regulator digunakan sebagai tegangan pada Arduino Uno. penstabil tegangan dari 12 volt accu motor

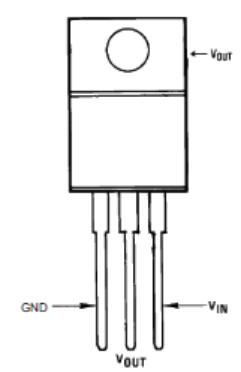

Gambar 3 : IC LM7805[7]

4. Display yang digunakan adalah LCD 16x2. LCD 16x2 memetakan 16 garis karakter dan memiliki 2 garis tampilan per karakter untuk ditampilkan dalam matriks $5 \times 7$ piksel. Jenis LCD ini memiliki dua jenis register, command dan perintah data[8]. LCD digunakan sebagai display penampil perhitungan pembacaan sensor yang sudah diolah oleh Arduino Uno.

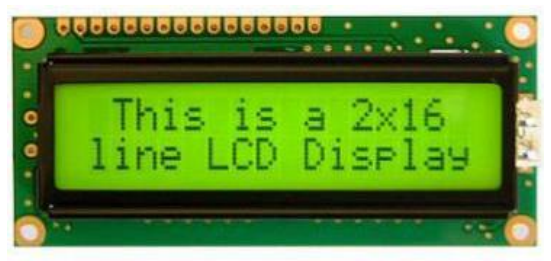

Gambar 4 : LCD $16 \times 2$

5. Light Emitting Diode (LED) merupakan indikator kecil di berbagai aplikasi komponen yang digunakan sebagai lampu konsumen[9]. LED yang digunakan pada 
ISSN 1979-4835

E-ISSN 2721-2335

aplikasi ini adalah LED warna merah dan

biru. LED warna biru digunakan sebagai sebagai tanda standby dan LED warna merah digunakan sebagai tanda bahwa kendaraan telah melampaui jarak tempuh yang telah ditentukan untuk melakukan penggantian oli.

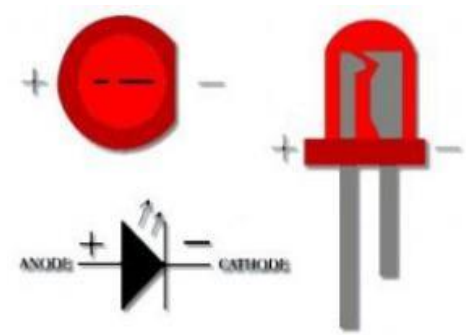

Gambar 5 : Simbol dan bentuk fisik LED

Berdasarkan penjelasan dari komponen yang digunakan, disusun blok diagram sistem seperti dijelaskan pada gambar 6.

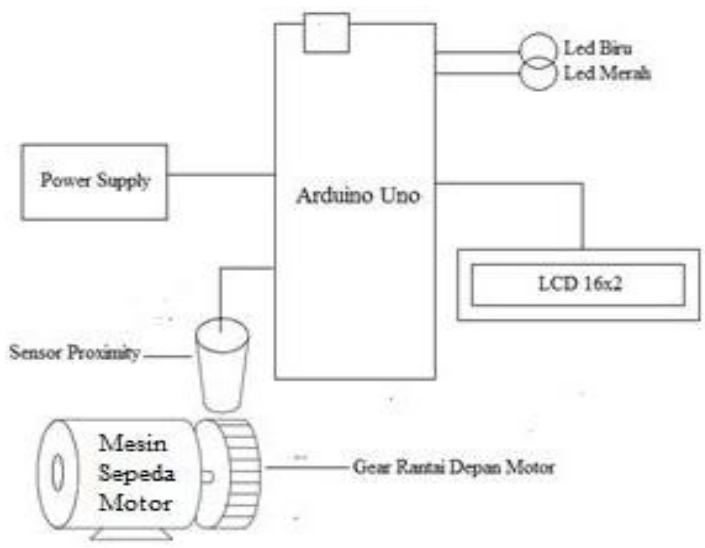

Gambar 6 : Blok Diagram Sistem[1]

Berdasarkan gambar diagram blok, sensor proximity induktif akan mendeteksi putaran logam yang menempel pada gear depan sepeda motor sehingga akan menghasilkan tegangan DC dalam bentuk sinyal pulsa. Kemudian data dari sensor akan diolah oleh Arduino uno dan akan menampilkan secara digital jarak tempuh, setelah melebihi jarak yang ditentukan untuk pergantian oli, lampu indikator menyala secara otomatis dan sistem akan memberi informasi berupa tulisan pada layar LCD bahwa oli harus diganti. Berikut adalah flowchart dari sistem yang direalisasikan. 


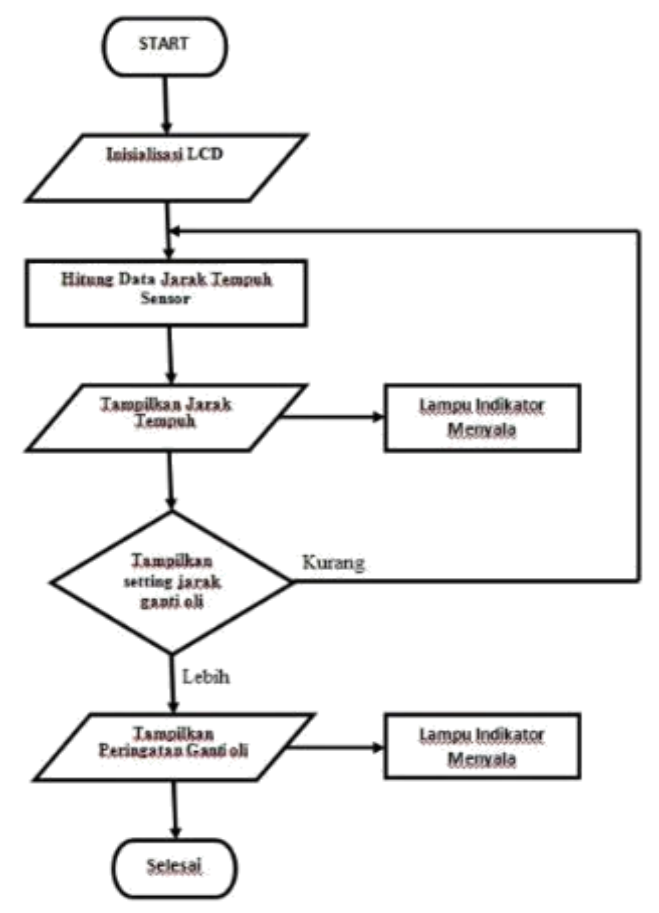

Gambar 7 : Flowchart Sistem

Dari flowchart, dapat diketahui bahwa ketika sistem dijalankan, LCD akan menyala dengan menampilkan tripmeter (jarak tempuh) dan juga LED biru akan menyala. Kemudian jarak tempuh yang terbaca oleh sensor proximity akan ditampilkan pada LCD. Jika jarak tempuh sudah melebihi batas yang telah ditentukan, maka LED merah akan menyala secara berkedip dan LCD akan menampilkan peringatan berupa pesan untuk segera melakukan pergantian

oli.

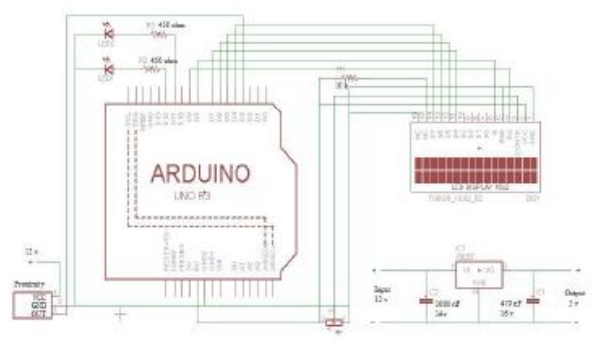

\section{Gambar 8 : Skematik Rangkaian Total}

\section{PENGUJIAN DAN ANALISA}

\section{Pengujian Sistem}

Bertujuan menguji kinerja dari sistem dan untuk mengetahui seberapa besar tingkat akurasi dalam membaca jarak yang ditempuh sepeda motor. peralatan yang digunakan dalam pengujian ini adalah sebuah sepeda motor 
ISSN 1979-4835

E-ISSN 2721-2335

Satria F 150 terutama pada bagian speedometer digital yang terdapat pada sepeda motor.

\section{Pengujian Catu Daya}

Bertujuan memastikan output tegangan dari catu daya tetap stabil sesuai dengan tegangan yang dibutuhkan oleh prototipe. Peralatan yang digunakan dalam pengujian ini adalah multimeter digital dengan komponen utama IC
Regulator LM7805 untuk menghasilkan output sebesar 5 volt.

Langkah - langkah pengujian yang dilakukan adalah sebagai berikut :

1. Menghubungkan rangkaian catu daya dengan aki motor.

2. Mengukur output dari rangkaian catu daya.

3. Mengamati output yang dihasilkan, memastikan output tegangan sekitar 5 volt.

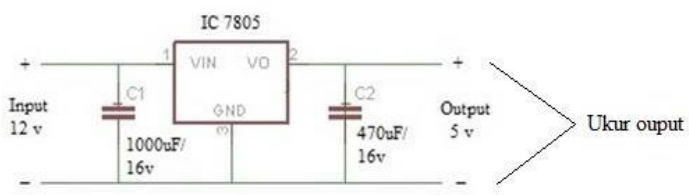

\section{Gambar 9 : Rangkaian pengujian catu daya 5 volt}

Berdasarkan pengujian yang dilakukan pada rangkaian catu daya didapatkan output sebesar 5,01 volt.

\section{Pengujian Arduino Uno}

Pengujian Board Arduino Uno Bertujuan untuk memastikan bahwa arduino yang digunakan dalam perancangan dapat berfungsi, sehingga program yang ditanamkan dapat beroperasi sesuai dengan perancangan.

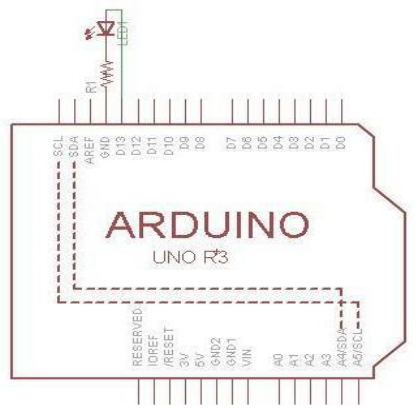

Gambar 10 : Pengujian Arduino Uno

Langkah - langkah yang dilakukan pada pengujian ini adalah :

Dengan meng-upload sketch program diatas,

1. Mengubungkan LED dengan board Arduino

2. Meng-upload sketch program ke Arduino maka LED akan menyala selama satu detik dan padam selama satu detik seterusnya. 


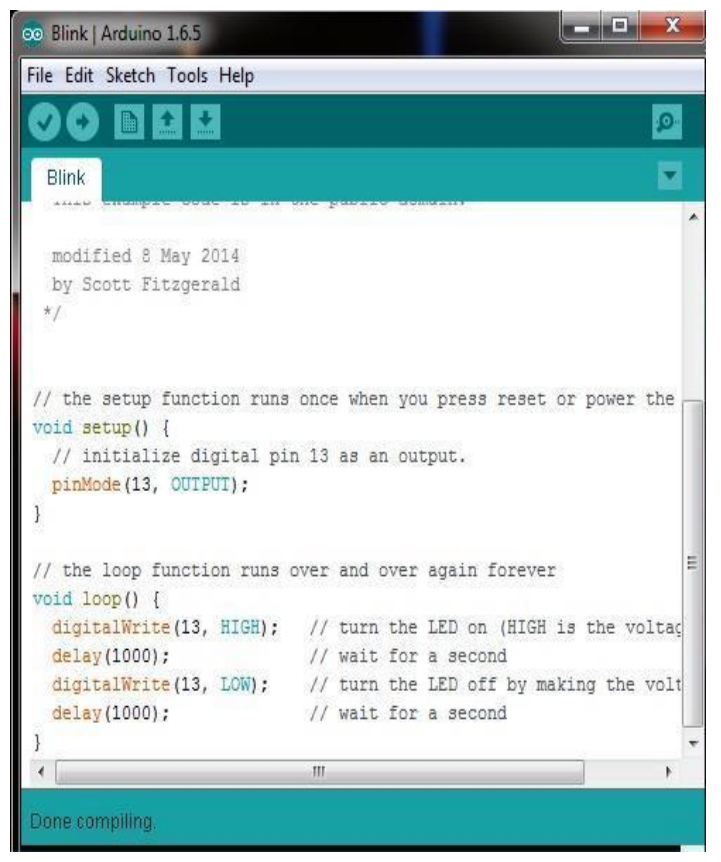

Gambar 11 : Sketch Program Pengujian Board Arduino Uno

\section{Pengujian LCD 16x2}

Bertujuan memastikan LCD dapat berfungsi, sehingga proses pembacaan jarak tempuh dapat ditampilkan pada layar LCD. Peralatan yang digunakan adalah sebagai berikut:
1. Catu daya.

2. Arduino Uno

3. LCD $16 \times 2$.

4. Kabel usb board Arduino Uno.

5. PC / Laptop.

6. Perangkat lunak (Arduino IDE).

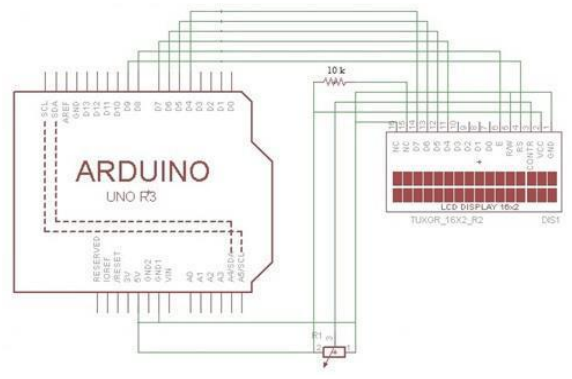

\section{Gambar 12 : Rangkaian pengujian LCD}

Langkah - langkah yang dilakukan pada pengujian ini antara lain :

1. Menghubungkan Catu daya, Arduino Uno, dan LCD 16x2
2. Meng-Upload sketch program ke Arduino Uno

3. Mengamati tampilan pada LCD, pastikan semua karakter benar 
ISSN 1979-4835

E-ISSN 2721-2335

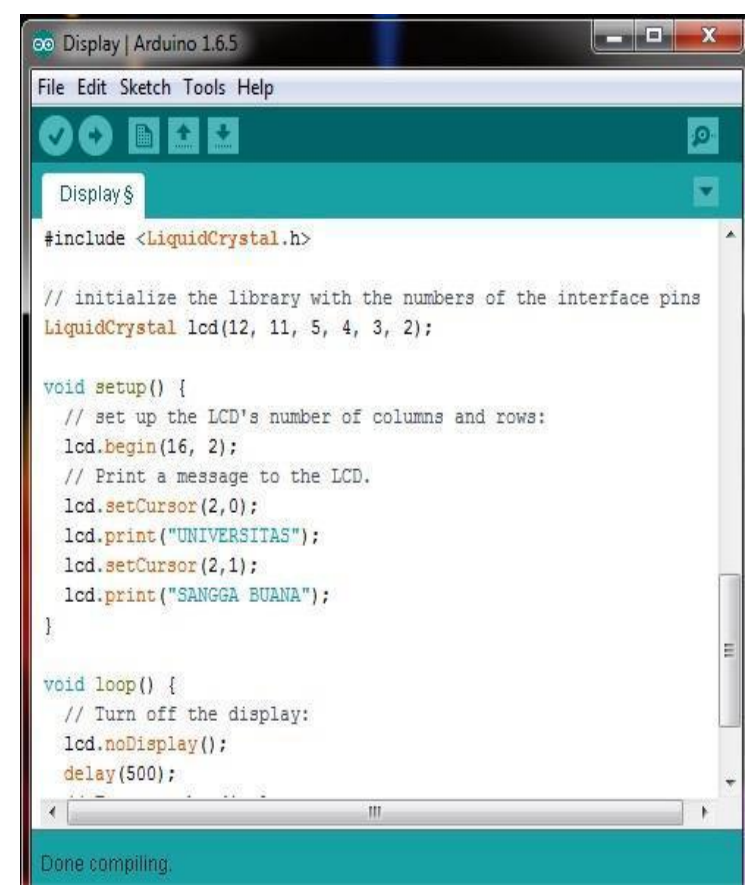

Gambar 13 : Sketch program pengujian LCD

Setelah melakukan pengujian, LCD dapat menampilkan karakter sesuai sketch program yang di-upload ke Arduino Uno.
Pada baris pertama menampilkan kata "UNIVERSITAS" dan baris kedua menampilkan kata "SANGGA BUANA".

Gambar 14 : Hasil pengujian LCD

\section{Pengujian Sensor Proximity Induktif}

Bertujuan untuk menguji kinerja dari sensor proximity induktif dan melihat tingkat akurasi pembacaan sensor. Alat-alat yang digunakan antara lain :

1. Catu Daya.

2. Arduino Uno.

3. Sensor sepeda motor.

4. Kabel usb board arduino uno.

5. PC / Laptop.
6. Perangkat lunak (Arduino IDE).

Langkah - langkah yang dilakukan pada pengujian ini antara lain :

1. Menghubungkan Catu Daya, Arduino Uno, dan Sensor Proximity.

2. Meng-upload sketch program ke Arduino Uno.

3. Amati hasil pembacaan sensor pada serial monitor arduino

IDE. 
ISSN 1979-4835

E-ISSN 2721-2335

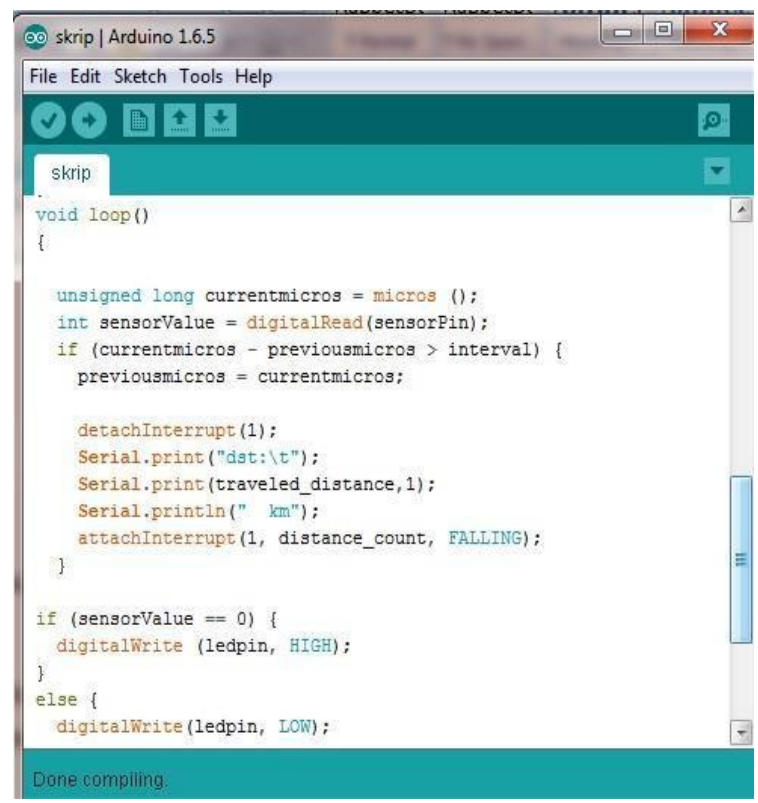

Gambar 15 : Sketch program pengujian sensor

Berdasarkan hasil pengujian, dapat mendeteksi adanya suatu objek yang dikatakan sensor berfungsi, karena mampu hasilnya ditampilkan pada serial monitor.

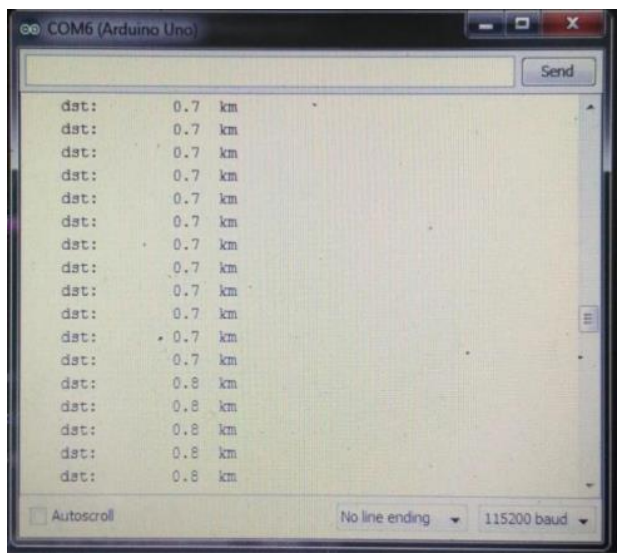

Gambar 16 : Hasil pengujian sensor

\section{Pengujian LED}

Bertujuan mengetahui apakah LED tersebut dapat menyala tidak, sehingga indikator LED pada rangkaian prototipe dapat bekerja sesuai perncanaan. Peralatan yang digunakan adalah sebagai berikuut:
1. Catu daya.

2. Arduino Uno.

3. LED.

4. Kabel usb board Arduino Uno.

5. PC / Laptop.

6. Perangkat lunak (Arduino IDE). 
ISSN 1979-4835

E-ISSN 2721-2335

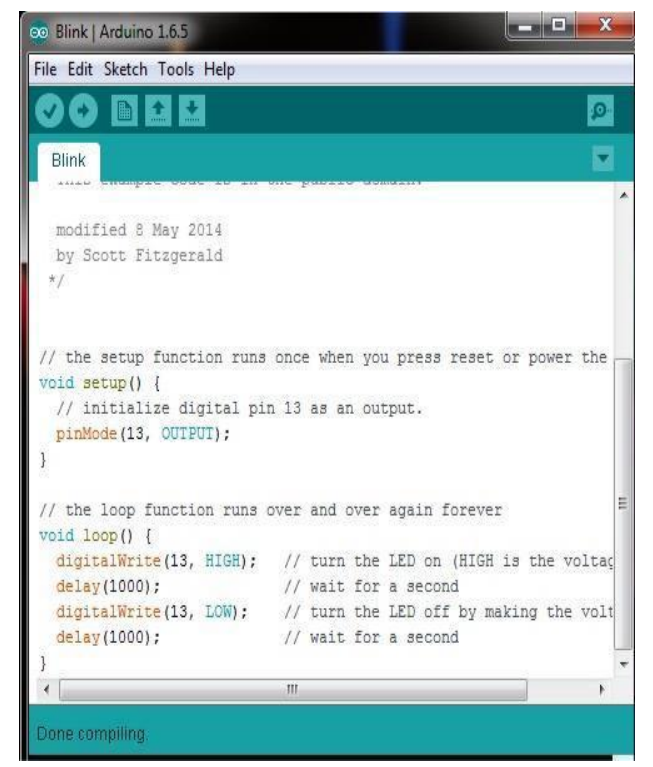

Gambar 17 : Sketch program pengujian LED

Langkah - langkah yang dilakukan pada pengujian ini antara lain :
3. melihat apakah LED menyala atau tidak.

1. Hubungkan Catu daya, Arduino Uno, dan LED.

Setelah melakukan pengujian dapat diketahui

2. Meng-upload sketch program ke bahwa

LED

dapat berfungsi. Arduino Uno

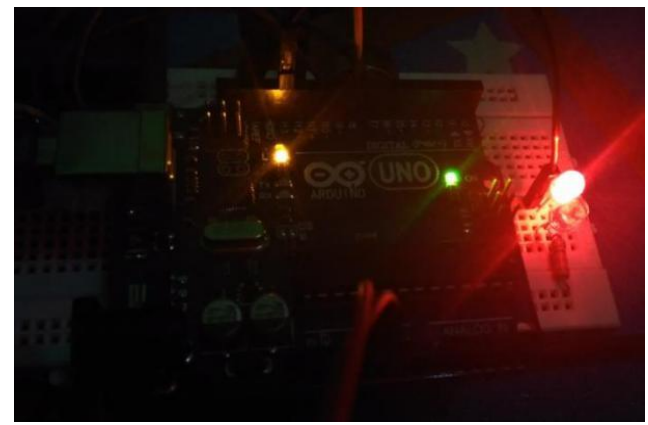

Gambar 18 : Hasil pengujian LED

\section{Pengujian Sistem}

Pengujian sistem bertujuan menguji kinerja dari sistem dan mengetahui seberapa besar tingkat akurasi sistem dalam membaca jarak yang telah ditempuh oleh sepeda motor. Adapun alat-alat yang digunakan adalah sebuah sepeda motor Satria F 150 terutama pada bagian speedometer digital yang terdapat pada sepeda motor.

Langkah - langkah yang dilakukan pada pengujian ini adalah sebagai berikut :

1. Mengubungkan rangkaian sistem dengan catu daya. 
2. Menyambungkan secara paralel kabel output sensor sepeda motor ke rangkaian.

3. Menyalakan sepeda motor.

4. Mengamati jarak tempuh pada sistem dan speedometer motor.

5. membandingkan hasil jarak yang terbaca oleh sistem dengan speedometer motor.

Setelah melakukan langkah di atas, terlihat bahwa sistem dapat berfungsi dan mampu mendeteksi jarak yang telah ditempuh sepeda motor dan menampilkannya pada LCD. Berikut merupakan perbandingan jarak yang ditampilkan oleh LCD dan speedometer. Dari data hasil pengujian dapat dihitung persentase akurasi jarak yang diukur oleh sistem dengan perhitungan sebagai berikut [1]:

$$
\begin{array}{r}
\Delta S=\left(S_{A}-S_{B}\right) \\
\text { dan } \\
A=\Delta S \times 100 \%
\end{array}
$$

Keterangan rumus :

$\mathrm{S}_{\mathrm{A}}$ : Jarak tempuh speedometer.

$\mathrm{S}_{\mathrm{B}}$ : Jarak tempuh ditampilkan oleh sistem.

$\Delta S$ : Selisisih jarak tempuh $S_{A}$ dan $S_{B}$.

A : Presentase akurasi jarak tempuh.

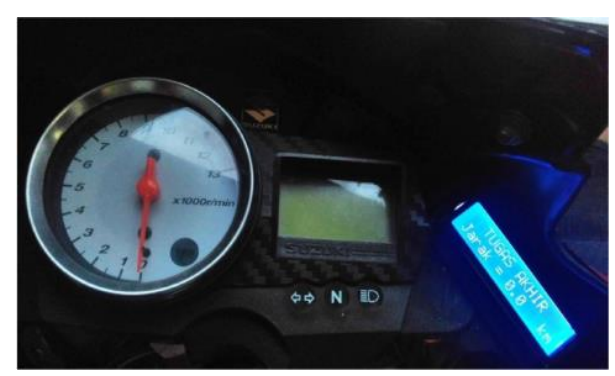

Gambar 19 : Hasil Realisasi Sistem

Tabel 2 Hasil pengujian sistem

\begin{tabular}{|c|c|c|c|c|}
\hline \multirow{2}{*}{$\mathrm{P}$} & \multicolumn{2}{|c|}{ Jarak tempuh } & $\Delta \mathrm{S}$ & $\mathrm{A}$ \\
\cline { 2 - 5 } & $\begin{array}{c}\mathrm{SA} \\
(\mathrm{km})\end{array}$ & $\begin{array}{c}\mathrm{SB} \\
(\mathrm{km})\end{array}$ & $(\mathrm{km})$ & $(\%)$ \\
\hline 1 & $1 \mathrm{~km}$ & $1,1 \mathrm{~km}$ & 0,1 & - \\
\hline 2 & $3 \mathrm{~km}$ & $3 \mathrm{~km}$ & 0 & $0 \%$ \\
\hline 3 & $5 \mathrm{~km}$ & $4,9 \mathrm{~km}$ & 0,1 & $10 \%$ \\
\hline 4 & $8 \mathrm{~km}$ & $7,9 \mathrm{~km}$ & 0,1 & $10 \%$ \\
\hline 5 & $10 \mathrm{~km}$ & $9,9 \mathrm{~km}$ & 0,1 & $10 \%$ \\
\hline
\end{tabular}

Keterangan tabel

$\mathrm{P}$ : Pengujian ke-

\section{Analisa Hasil Pengujian Sistem}

Hasil pengujian sistem dapat menampilkan jarak tempuh sistem yang sesuai dengan speedometer, namun terjadi perbedaan hasil tampilan dan error pada sistem yang disebabkan karena beberapa hal antara lain : 
1. Adanya perbedaan titik awal saat memulai perhitungan antara sistem dan speedometer asli.

2. Sistem mengalami kondisi error jika sepeda motor di starter dengan menggunakan power yang sama dari aki sepeda motor. Adanya kondisi tersebut menyebabkan tampilan LCD menjadi tidak beraturan. Untuk menjadikannya kembali normal perlu dilakukan restart pada board Arduino Uno.

3. Pada saat melakukan perngukuran jarak, terkadang terjadi delay pada hasil yang ditampilkan di LCD. Saat sistem kembali normal, dapat dilakukan kembali perhitungan jarak selanjutnya dengan melewati perhitungan saat terjadi delay tadi.

4. Sistem ini akan berjalanan ketika mesin kendaraan dalam keadaan menyala. Apabila mesin kendaraan dimatikan maka sistem akan melakukan perhitungan jarak tempuh dari awal lagi. Oleh karena perlu ditambahkan IC EEPROM untuk menyimpan data jarak yang sudah ditempuh oleh kendaraan pada saat mesin dimatikan. Sehingga pada saat mesin kendaraan dihidupkan kembali, pembacaan jarak tempuh akan melanjutkan data yang sebelumnya sudah terbaca.

\section{KESIMPULAN}

Dari hasil pembahasan tentang perancangan dan realisasi sistem dapat diambil kesimpulan, antara lain :
1. Sistem dapat berfungsi normal, dengan menampilkan nilai pengukuran jarak saat sepeda motor dijalankan

2. Tampilan jarak tempuh sistem melakukan update jarak setiap menempuh jarak 100 meter.

3. Persentase akurasi alat mencapai $10 \%$ pada total jarak $10 \mathrm{~km}$.

Dalam perancangan dan pembuatan sistem ini masih banyak kekurangan yang perlu diperbaiki untuk menyempurnakan sistem. Maka untuk tahap pengembangan selanjutnya, ada beberapa bagian dari alat ini yang perlu dilakukan penyempurnaan antara lain :

1. Sistem harus dilengkapi dengan IC EEPROM atau SD Card supaya data jarak yang telah ditempuh akan tetap tersimpan walaupun mesin kendaraan dalam keadaan mati.

2. Sistem ini bisa digunakan untuk diaplikasikan pada sepeda motor dengan spedometer analog dengan menggunakan sensor hall effect.

3. Alat dapat dikembangkan dengan fitur atau aplikasi lain yang terkoneksi langsung dengan GPS, untuk menambah keakuratan pengukuran jarak.

\section{DAFTAR PUSTAKA}

[1] A. Trisetiyanto and - Djuniadi, "PENGEMBANGAN SISTEM PERINGATAN GANTI OLI PADA SEPEDA MOTOR," J. Tek. Elektro, 2011.

[2] M. Iirsyam, "PERANCANGAN ALAT 
PENDETEKSI KELAYAKAN OLI PADA KENDARAAN SEPEDA MOTOR BERBASIS ARDUINO UNO ATMEGA328," SIGMA Tek., 2019, doi: 10.33373/sigma.v2i2.2061.

[3] E. Widiantono and T. Sukmono, "Analisis Antrian Service Motor di Dealer Resmi Honda," PROZIMA (Productivity, Optim. Manuf. Syst. Eng., 2018, doi: 10.21070/prozima.v1i2.1297.

[4] R. A. Santana, D. Risqiwati, and Z. Sari, "Rancang Bangun Sistem Informasi Servis Oli Sepeda Motor Menggunakan Odometer Berbasis LBS, " KINETIK, 2017, doi: 10.22219/kinetik.v2i1.98.

[5] Rachmat Farhan, Muhaimin, and Maimun, "RANCANG BANGUN TEMPAT SAMPAH PINTAR PADA GEDUNG JURUSAN TEKNIK ELEKTRO BERBASIS
MIKROKONTROLER ARDUINO MEGA 2560," J. TEKTRO, 2019.

[6] B. S. Ivany Sarief, Wulandari Pancadasa Merdeka Putri, "Perancangan Dan Realisasi Purwarupa Sistem Monitoring Area Parkir Mobil Dengan Menggunakan Ultrasonik dan Light Dependent Resistor," Infotronik J. Teknol. Inf. dan Elektron., 2018.

[7] Texas Instruments, "LM340, LM340A and LM7805 family wide Vin 1.5-A fixed voltage regulators," Data Sheet, 2017.

[8] elektronika Dasar, "LCD (Liquid Cristal Display)," ElektronikaDasar.Web.Id. 2012.

[9] K. Streubel, "Light-emitting diodes (LEDs)," in Handbook of Optoelectronics, Second Edition: Concepts, Devices, and Techniques, 2017. 